\title{
PENNSYLVANIA TENTATIVE TRUSTS: PROBLEMS AND PROBLEM AREAS
}

\author{
Donatd S. CoHan $\dagger$
}

The general outlines of the law of tentative trusts are well settled in Pennsylvania. By adopting the Totten trust doctrine, ${ }^{1}$ the courts have defined the rights of the depositor during his lifetime and the beneficiary following the death of the depositor. ${ }^{2}$ However, the application of these principles is affected by the rights and duties of third parties under state statutory and common law. This interaction suggests an examination of Pennsylvania tentative trust law with respect to: (1) claims against the trust account (by creditors, surviving spouse, and taxing authorities) ; (2) rights, duties, and obligations of savings institutions; and (3) treatment of special groups (minors, incompetents, and charities).

\section{Claims Against the Trust Account A. Creditors' Rights}

Funds in an "in trust" account may be reached after the death of the depositor for the payment of his debts and the administrative expenses of his estate, but only if the decedent "has not sufficient other property which can be applied for these purposes." 3 It is equally clear that the depositor's creditors can reach the trust account during his lifetime. ${ }^{4}$

$\dagger$ A.B. 1951, Amherst College; LI.B. 1954, Harvard University. Member, Pennsylvania Bar. The author is appreciative to David B. Zoob, Esquire, who encouraged and aided the preparation of this Article.

1 In 1933 the Pennsylvania Supreme Court adopted the New York rule as set forth in In re Totten, 179 N.Y. 112, 71 N.E. 748 (1904). Scanlon's Estate, 313 Pa. 424, 169 Atl. 106 (1933); see Rodger's Estate, 374 Pa. 246, 97 A.2d 789 (1953); Bearinger's Estate, 336 Pa. 253, 9 A.2d 342 (1939) ; Pozzuto's Estate, 124 Pa. Super. 93, 188 A.2d 209 (1936). But see Ingel's Estate, 372 Pa. 171, 180, 92 A.2d 881, 885 (1952) (dissenting opinion). Prior to 1933, Pennsylvania courts had formulated the rule that the labelling of a bank account as a trust raises a presumption that a valid trust is created. Rambo v. Pile, $220 \mathrm{~Pa}$. 235, 69 Atl. 807 (1908); Arnold v. Macugnie Sav. Bank, 71 Pa. 287 (1872) ; Kelly v. General Fin. Co., 16 Pa. D. \& C. 435 (C.P. 1931).

2 See, e.g., Scanlon's Estate, supra note 1; Krewson Estate, 154 Pa. Super. 509, 36 A.2d 250 (1943) ; Gorgas Estate, 147 Pa. Super. 319, 24 A.2d 171 (1942) ; Fairweather Estate, 9 Chester 99 (Pa. Orphans' Ct. 1959); Kowalenko Estate, 73 Montgomery 523 (Pa. Orphans' $\mathrm{Ct}$ 1951).

3 Rodger's Estate, 11 Fid. Rep. 645, 647 (Pa. Orphans' Ct. 1961), quoting RESTATEMENT (SECOND), TRUSTS $\$ 58$, comment $d$ (1959); see 1 ScotT, Trusts $\$ 58.5$, at $497-98$ (2d ed. 1956).

4 See Banca D'Italia \& Trust Co. v. Giordano, 154 Pa. Super 452, 455, 36 A.2d 242, 243 (1944); Wagner Estate, 86 Pa. D. \& C. 454 (Orphans' Ct. 1953) (dictum); 1 Scotr, Trusts $\$ 58.5$, at 497 (2d ed. 1956). 
At the death of the depositor, it seems obvious that the creditors of the beneficiary can reach the property held in the trust account, since the fund becomes the property of the named beneficiary at that time. ${ }^{5}$ While the depositor is living, creditors of a beneficiary of a tentative trust have no present claim to the funds in the trust; ${ }^{6}$ an attachment of such a trust account during the life of the depositor by a creditor of the beneficiary constitutes an interference with the right of the depositor to maintain control over the deposit. ${ }^{7}$

At least twice it has been held that in the event of insolvency of the savings institution, the depositor may not set off the tentative trust against debts owed by him to the bank. ${ }^{8}$ Both cases are based on the theory that a tentative trust is an actual trust until revoked, but conflict sharply with the rule allowing creditors of the depositor to reach the account even though he has not exercised his right of revocation. Theoretically, the conflict may be reconciled. In the case of the depositor's creditors, it may be argued that it is the unrestricted control of the depositor over the account and not his property interest therein which allows creditors to reach the fund ${ }^{9}$ hence, it is not wholly illogical to assert in setoff cases that the account is not the property of the depositor. ${ }^{\mathbf{1 0}}$

Apart from such rules, it would be easy for the depositor to resort to self-help, since his subjective intent forms the key to most problems in this area. ${ }^{11}$ He could assert an irrevocable trust in cases in which his creditors threatened ${ }^{12}$ and a revocable trust subject to setoff in cases where the bank became insolvent. Unfortunately, in trying to avoid such manipulation, the courts have gone beyond the pale of fairness. It seems inequitable to allow a creditor bank to reach the deposit, yet not permit the depositor his setoff against an insolvent bank in identical accounts.

\section{B. Rights of the Surviving Spouse}

Whether the rights of a surviving spouse can be defeated by the use of "in trust" bank accounts is important, because such accounts

5 Doubtless, however, the creditors of the depositor would have first claim to the trust account.

Bankruptcy Act $\$ 70$ (a)(3), 52 Stat. 880 (1938), as amended, 11 U.S.C. $\$ 110$ (a) (3) (1958).

7 Kelly v. General Fin. Co., 16 Pa. D. \& C. 435 (C.P. 1931).

8 Kardon v. Willing, 20 F. Supp. 471 (E.D. Pa. 1937); In re Erie Trust Co., 20 Erie 83 (Pa. C.P. 1938).

${ }^{9}$ See Banca D'Italia \& Trust Co. v. Giordano, 154 Pa. Super. 452, 455, 36 A.2d

242, 243 (1944); RESTATENENT (SECOND), TRUSTS $\$ 58$, comment $d$ (1959).

10 See 36 Mich. L. REV. 517 (1938); 86 U. PA. L. Rev. 321 (1938).

11 See Ingel's Estate, 372 Pa. 171, 174, 92 A.2d 881, 882 (1952). (1943).

12 See Banca D'Italia \& Trust Co. v. Giordano, 154 Pa. Super. 452, 36 A.2d 242 
often appear as substitutes for wills. ${ }^{13}$ Under section 11 of the Estates Act of 1947,14 Pennsylvania allows the surviving spouse of a depositor to reach such an account as part of his or her statutory share. ${ }^{15}$ In applying these provisions to tentative trusts, the case law treats such trusts as illusory transfers conveying no vested rights. The court in Graham Estate ${ }^{16}$ stated that section 11 applies to tentative trusts because the depositor retains a power of revocation, and in Krasney Estate ${ }^{17}$ the court allowed a surviving wife to reach the deposit on three alternative grounds, one of which was that section 11 allows a surviving spouse to treat a tentative trust as a testamentary disposition.

Although section 11 is not retroactive in its application, ${ }^{18}$ one recent lower court opinion ${ }^{19}$ holds that it applies to a tentative trust created prior to the effective date of the act because the conveyance became effective at the death of the depositor, after the act, rather than at the time of creation. Since the basis for allowing a spouse to reach the account under the Pennsylvania common-law rules is that the transfer creates no vested rights, it may be unnecessary to apply the statute retroactively in tentative trust cases. However, the courts have recognized the inchoate character of beneficiaries' rights in savings account trusts. ${ }^{20}$

It would seem that Pennsylvania applies the better rule in allowing the spouse to elect against a tentative trust. Although a depositor should be allowed to transfer assets at his death without the formalities of estate administration, he should not be permitted to use a savings deposit as a means of defeating the strong public policy protecting his spouse's claim to her statutory share and accomplishing with a tentative trust something he could not do with a will.

\section{Rights of Taxing Authorities}

The old Pennsylvania Transfer Inheritance Tax Act ${ }^{21}$ taxed property transferred by a decedent "when the transfer is . . . made in

13 See Leapheart, The Trust as a Substitute for a Will, 78 U. PA. L. Rev. 626, $637(1930)$.

14 PA. Stat. ANN. tit. 20, §301.11 (Supp. 1961).

15 Compare Vache Estate, 9 Fid. Rep. 465 (Pa. Orphans' Ct. 1959) (widow could not take against "in trust" account, although taking against will, because she did not file under $\$ 11$ ).

$163 \mathrm{~Pa}$. D. \& C.2d 218 (Orphans' Ct. 1954).

$1710 \mathrm{~Pa}$. D. \& C.2d 450, 456-59 (Orphans' Ct. 1957). The same reasoning was used by the court in Williams Estate, 12 Fid. Rep. 285 (Pa. Orphans' Ct. 1962), where the court permitted the husband of a decedent to receive his "family exemption" as well as his statutory share from the proceeds of a tentative trust.

18 See, e.g., Iafolla Estate, $380 \mathrm{~Pa}$. 391, 396, 110 A.2d 380, 382 (1955) ; Bullock Estate, 79 Pa. D. \& C. 389, 393 (Orphans' Ct. 1951).

${ }_{19}$ Krasney Estate, 10 Pa. D. \& C.2d 450 (Orphans' Ct. 1957); see Iafolla Estate, supra note 18, at 396, 110 A.2d at 382-83 (dictum).

20 See cases cited notes 16-17 supra.

$21 \mathrm{~Pa}$. Laws 1919, act 521, §1. 
contemplation of ... death ... or intended to take effect in possession or enjoyment at or after . . . death." It further provided a rebuttable presumption that transfers made within a year of death were "made in contemplation of death within the meaning of this clause." The courts have held tentative trusts taxable under this language. ${ }^{22}$

The Commissioner's comment to section 226 of the Inheritance and Estate Tax Act of $1961^{23}$ (effective January 1, 1962) states that the new statute is consistent with the existing case law. It taxes such transfers where the decedent "has, at his death, either in himself alone, or in conjunction with any person not having an adverse interest, a power to alter, amend or revoke the interest of the beneficiary . . . ."24

If the savings account trust remains subject to the absolute control of the depositor-that is, so long as it remains a tentative trust-, the interest earned on the account is includible in the depositor's taxable income. ${ }^{25}$ Similarly, under section 2038 of the Internal Revenue Code of 1954 , the decedent's gross estate will include a savings account trust whenever it is still "tentative" at the time of death.

When a testator directs that his residuary estate bear all taxes on the legacies given in his will, such a direction will not relieve the beneficiary of a tentative trust account from payment of the federal and state taxes levied on the estate by reason of the trust. ${ }^{26}$

If the funds of an "in trust" account are taxable to the depositor's estate under federal or state law, the personal representative of the depositor is under a duty to report the account on the appropriate return. ${ }^{27}$ Further, since it is part of the responsibility of a personal representative to gather the assets of the estate over which he has charge, ${ }^{25}$ he should inquire into the background of any "in trust" deposit maintained by the decedent in order to ascertain whether such funds are properly includible in the estate. In some cases, this may obligate the personal representative to block the account by notifying the bank as provided in the Banking Code ${ }^{29}$ and either to post the necessary bond or to obtain the court order required by that statute.

22 Doherty Estate, 12 Fid. Rep. 185 (Pa. Orphans' Ct. 1961) ; Peterman's Estate, $56 \mathrm{~Pa}$. D. \& C. 365 (Orphans' Ct. 1946) ; Kress Estate, 92 Pittsb. 553 (Pa. Orphans' Ct. 1943) ; Flannery's Estate, 34 Pa. D. \& C. 165 (Orphans' Ct. 1938).

23 PA. STAT. ANN. tit. 72, §2485-226 (Supp. 1961). It would seem that this language modifies the Pennsylvania rule with regard to taxation of revocable trusts.

24 See Dolan's Estate, 279 Pa. 582, 124 Atl. 176 (1924) (power to revoke or amend in settlor alone).

25 See INT. REv. Code of 1954, $\S \S 671,676$. Conversely, it seems likely that no gift tax would be due because no taxable transfer has been made.

26 See Kyle Estate, 1 Fid. Rep. 131 (Pa. Orphans' Ct. 1947).

27 See INT. Rev. Code of 1954, §2002; PA. Stat. ANN. tit. 72, §§ 2485-701, -731 (Supp. 1961).

28 PA. STAT. AnN. tit. 20, §320.501 (1950).

29 Pa. Stat. ANN. tit. 7, § 819-905 (1939). 


\section{Rights, Duties, and Obligations of Savings Institutions}

The institution in which an "in trust" account is maintained normally has two general desires with respect to such accounts-that the purposes and intentions of the depositor be honored and that liability for wrongful payment of funds be avoided. The Banking Code, the Building and Loan and Savings and Loan Laws, and the contractual arrangements between bank and depositor provide the basis for discussion in this area.

\section{A. The Statutes}

The Banking Code sets forth a bank's rights and duties in the handling of "in trust" accounts. Under section 904,30 the bank "may" pay the funds of such an account to the named beneficiary "upon satisfactory proof of the death of the person . . . described as trustee," provided that the bank has received no notice in writing "of the existence and terms of a valid trust [other] than such [as] . . . shall have been given in writing" to the bank. Under section $905 \mathrm{~A},{ }^{31}$ the bank is permitted to disregard notices of adverse claims to accounts unless the notice is in the form of a restraining order or attachment or accompanied by a bond "acceptable" to the bank indemnifying it "from any liability, loss, damage, costs or expenses on account of the payment of such adverse claim or the dishonor of the check or other order of the . . . person to whose credit the deposit stands on the books of the institution." Section 905A applies to all situations except those in which "the person to whose credit the deposit stands is a fiduciary for such adverse claimant" and in which claimant gives to the bank his affidavit stating "the facts constituting such [fiduciary] relationship, as well as the facts showing reasonable cause of belief . . that such fiduciary is about to misappropriate the deposit "32

Such statutory announcements allow banks to rely upon their records in all cases except those in which they are in receipt of notice in proper form that there is an adverse claim to the fund in question. Where such notice is given, the bank can bring the adverse parties into court and have the ownership of the funds decided by judicial action. ${ }^{33}$ Or, if the bank has reason to believe that the claimant is not the

30 Pa. Stat. AnN. tit. 7, §819-904 (1939).

31 Pa. Stat. ANn. tit. 7, \$ 819-905A (1939).

32 Pa. Stat. Ann. tit. 7, §819-905B (1939).

33 See Vierling v. Ellwood City Fed. Sav. \& Loan Ass'n, $356 \mathrm{~Pa} .350,52$ A.2d 224 (1947); Merigan v. McGonigle, $205 \mathrm{~Pa}$. 321, 54 Atl. 994 (1903); Waltman v. Germantown Trust Co., $92 \mathrm{~Pa}$. Super. 480 (1928); cf. Iafolla Estate, $380 \mathrm{~Pa}$. 391, 110 A.2d 380 (1955). 
proper person to receive the funds, it may refuse to pay even though it would be protected against mispayment by the provisions of section 904 of the Banking Code. ${ }^{34}$ On the other hand, payment in disregard of the proper notice of adverse claims may result in liability to the true owner of the fund. ${ }^{35}$

Similar provisions apply to federal savings and loan associations $^{36}$ and to building and loan associations. ${ }^{37}$ They permit the association to rely on its records and provide that after the member's death a receipt from the beneficiary of record-provided the beneficiary is not less than sixteen years old-_"shall be a full, complete and valid release of the . . association from any further liability of the accounts so paid."

\section{B. The Olney Bank \& Trust Case}

In most cases a bank would be justified in paying the fund to the executor of its "trustee" depositor. In the Olney Bank \& Trust Case, ${ }^{38}$ the claimant, record beneficiary of an "in trust" account created by a deceased depositor, attempted to hold the bank for wrongful payment of the account to the administrator of the depositor's estate. In denying this claim, the court rested its decision upon two grounds"the general rule. . . that upon the death of a trustee of personal property . . . where no successor has been appointed by the proper court, the property held in trust goes to the personal representative of the deceased trustee [in trust]," 39 and the bank rule that "the legal representative or successor of the decedent shall alone be entitled to receive payment and his or their receipt with the production of the deposit book will be in full discharge to the bank." 40 The opinion could be supported on either of these grounds. ${ }^{41}$ There might be some question as to the ruling if such a bank rule were not involved when one considers that the bank has a perfectly safe course under section 904 of the Banking Code and by interpleader.

Speculation as to the result of the Olney Bank \& Trust Case decision had the claimant been the administrator and the bank had defended a payment to the record beneficiary by asserting the per-

34 See Miller v. Beneficial Sav. Fund Soc'y, 36 Pa. D. \& C. 304 (C.P. 1939).

35 See Downey v. Duquesne City Bank, 146 Pa. Super. 289, 22 A.2d 124 (1941); Waltman v. Germantown Trust Co., 92 Pa. Super. 480, 485 (1928); cf. Gaffney's Estate, $146 \mathrm{~Pa}$. 49, 23 Atl. 163 (1892).

30 See Pa. Stat. ANN, tit. 15, §1081.3 (1958).

37 See PA. Stat. ANN. tit. 15, \$1074-610 (Supp. 1961).

$38116 \mathrm{~Pa}$. Super. 438, 176 Atl. 837 (1935).

39 Id. at 441,176 Atl. at 837 .

40 Id. at 442,176 Atl. at 839 .

41 Ibid. 
missive provisions of section 904 of the Banking Code proves interesting. The administrator could argue that, notwithstanding the statute, the bank rules constitute a contract between it and its depositor that it would pay only the depositor or his representative. Payment to the beneficiary breaches this contract and results in a loss to the estate. Under such reasoning, the bank in the Olney Bank \& Trust Case was not only justified in paying the administrator, but might not have been safe in paying the beneficiary except pursuant to a court order. While the case may thus create an inference that a bank's rules can alter the effect of the statutory provisions permitting payment to the record beneficiary, such rules would not justify a bank in paying in defiance of proper notice of an adverse claim. ${ }^{42}$

Once the bank has paid over the funds in accordance with section 904 , it cannot later be required to pay them into court, for such payment ends the bank's responsibilities. ${ }^{43}$ But such payment would not affect the rights of other persons to the fund in the hands of the beneficiary. 44

\section{Notification and Payment}

There seems to be no duty imposed on a bank to notify a beneficiary of the death of an "in trust" depositor. The bank has no obligation to do anything but wait until it is approached by the beneficiary or the depositor's personal representative. ${ }^{45}$

Upon notification by the beneficiary or the personal representative of the death of the depositor, the bank ordinarily could pay the funds to the beneficiary in accordance with the "permissive" statutes or hold them subject to determination of the rights to the account. ${ }^{46}$ Under certain circumstances, it might be justified in paying the funds to the personal representative. ${ }^{47}$ The statutory provision that after the depositor's death the amounts on deposit "shall be . . . paid to the person or persons for whose benefit" the shares were purchased ${ }^{48}$ places building and loan and federal savings and loan associations in a slightly different position. This mandatory payment provision makes it dangerous for the association to pay funds to the member's exec-

42 See cases cited note 35 supra.

43 Del Conte v. Luca, 2 Pa. D. \& C.2d 130, 135 (C.P. 1954).

44 See Restatement (Second), Trusts $\$ 58$, comment $f$ (1959).

45 But see $\$ 742$ of the Inheritance and Estate Tax Act of 1961, PA. Stat. ANN. tit. 72, \$2485-742 (Supp. 1961), which obligates banks to report the existence of "in trust" accounts for inheritance tax purposes.

46 Miller v. Beneficial Sav. Fund Soc'y, 36 Pa. D. \& C. 304 (C.P. 1939).

47 See notes 38-42 supra and accompanying text.

48 See Pa. Stat. Ann. tit. 15, $\$ 1074-610$ (Supp. 1961); Pa. Stat. Ann. tit. $15, \S 1081.3$ (1958). 
utor since it may also be required to pay the beneficiary if he presents adequate identification and proof of age to the association.

It should be noted that the Banking Code requires that the beneficiary be paid unless the bank is given "notice of the existence and terms of a valid trust [other] than such description [of the depositor in trust for another] . . . in writing." 49 The relevant provisions relating to building and loan and federal savings and loan associations contain no express requirement that such notice of other trust terms be in writing. ${ }^{50}$ In order to avoid possible demands by persons who claim benefits under unwritten notice of trust provisions, associations should (a) instruct their employees to channel any such notice to a responsible officer of the association who is required to reduce the new designation to writing and (b) have a rule paraphrasing the provisions of the Banking Code as to writings and make the rule binding on the member by a reference to it in the passbook, share certificate, or signature card.

\section{Passbooks: "Receipt or Acquittance"}

There seem to be no requirements in the Banking Code relating to the issuance of passbooks, and it appears that the use of a passbook is discretionary with the bank. So far as the beneficiary's claims are concerned, a bank is empowered to pay out on the beneficiary's "check, order, or receipt, as the case may be" upon proof of the death of the depositor. ${ }^{51}$ Thus it seems clear that where the funds are in a bank, the beneficiary may claim the account without presenting any passbook, and the bank is within its rights in paying the funds to him. The same is true as to federal savings and loan associations, so far as they may be controlled in these matters by Pennsylvania law. They are permitted to pay out upon the "receipt or acquittance" of the beneficiary. ${ }^{52}$

Similarly, the Building and Loan Code provides for payments to the beneficiary upon his "receipt or acquittance." 53 But this code requires that when the funds are withdrawn, "the original certificate shall be surrendered . . . for cancellation." 54 This language raises some question as to payments made solely upon the "receipt or acquittance" of a beneficiary. However, a building and loan association probably would be justified in paying without surrender of the share

49 Pa. Stat. Ann. tit. 7, \$ 819-904 (1939).

50 See Pa. Stat. AnN. tit. 15, $1074-610$ (Supp. 1961); Pa. Stat. Ann. tit. $15, \S 1081.3(1958)$.

51 PA. STAT. ANN. tit. 7, \$ 819-904 (1939).

52 PA. Stat. ANN. tit. 15, § 1081.3 (1958).

53 PA. Stat. ANN. tit. 15, § 1074-610 (Supp. 1961).

54 Pa. Stat. ANN. tit. 15, \& 1074607 (1958). 
certificate either on the fact that the code elsewhere speaks of payments of the withdrawal value or maturity value and not of the surrender of the shares or on the fact that the intention of the first provision mentioned is to enable the beneficiary to obtain the funds solely on his signature.

\section{E. Voting of Shares}

Section 506 of the Building and Loan Code ${ }^{55}$ provides that when a fiduciary who holds shares of a building and loan association in trust is appointed other than by will or by a decree of the orphans' court, the shares "may be voted by such fiduciary . . . either in person or by proxy." In the cases excepted above, the shares are to be voted "in the manner and under the circumstances provided by law." In the typical "in trust" case, in which the "trustee" appoints himself, he may vote the shares. This is the only logical result, for otherwise the association would deny the shareholder's vote to a person who, so far as it is concerned, owns the account and can reduce, close, or otherwise deal with it as he pleases. It is somewhat doubtful that a holder of an "in trust" share certificate is a fiduciary within the meaning of section 506 or within the common-law meaning of fiduciary. The existence of the certificate implies that the shareholder has all rights of ownership until his death-and possibly thereafter if his will so provides. Thus the beneficiary's rights in such an "in trust" certificate would be far different from the rights of a beneficiary under a will or deed of trust.

\section{F. Using Name or Funds of Another}

When a depositor creates an "in trust" account, using his own funds but giving an assumed name as trustee in trust for an existing third person, the account is treated as though the depositor had opened it in his own name. ${ }^{56}$ The use of an assumed name does not vary or affect the application of the usual tentative trust rules.

However, the use of an assumed name may create difficulties of proof. Even after the depositor has died without disturbing the tentative trust, the beneficiary is not able to reach the fund until it has been shown that the depositor has created that account for himself under an assumed name rather than as a gift to the person bearing the assumed name. In one case, ${ }^{57}$ such a showing was based on proof of

55 Pa. Stat. AnN. tit. 15, §1074 (1958), as amended, PA. Stat. AnN. §§ 1074-3 to -1112 (Supp. 1961).

56 Migut Estate, 30 Luzerne 38 ( $\mathrm{Pa}$. Orphans' Ct. 1935).

57 Ibid. 
the understanding of the bank employees and officers that the depositor had adopted the assumed name for the purpose of the account and further proof that he had a safe deposit box also under the assumed name. Even with such proof, the court required notice to the person whose name was used as the assumed name.

The deposit of money rightfully belonging to another in an "in trust" account does not prevent the true owner from reaching the funds so deposited. ${ }^{58}$ However, the depository may pay the funds to the depositor or even seize the account for its claim against the depositor unless it has knowledge that the funds on deposit belong to someone other than the depositor. ${ }^{59}$

\section{Treatment of Special Groups}

\section{A. The Position of Minors}

Pennsylvania statutes permit-or require-banks, building and loan associations, and federal savings and loan associations to deal with minor beneficiaries and depositors.

A depository subject to the Pennsylvania Banking Code ${ }^{60}$ may, pursuant to section 902 thereof, receive deposits in the name of a minor. ${ }^{81}$ This section states that the bank "shall" pay out the funds so deposited upon receipt of the minor depositor's "proper check, order, or receipt, as the case may be, without the assent of [the minor's] parent or guardian." Curiously, the provision seemingly applies regardless of the age of the minor depositor. Members subject to the Pennsylvania Building and Loan Code or the Pennsylvania statutes relating to federal savings and loan associations are similarly situated save that in these cases the minor need not be paid on his own order if he is less than twelve years of age. ${ }^{62}$

All of these statutory provisions apply when a minor deposits funds "in trust." When funds are deposited "in trust" for a minor, slightly different rules apply. Section 904 of the Banking Code ${ }^{63}$ provides that when a bare "in trust" account-one in which the bank

58 Thus, in Drusbasky v. Drusbasky, 83 Pittsb. 489 (Pa. C.P. 1935), a son was able to compel his mother to account for money earned by him after coming of legal age and turned over to her and deposited by her in an account "in trust" for him. And in Bibby v. Bibby, $241 \mathrm{~Pa} .175,88$ Atl. 416 (1913), a husband was able to reach funds "in trust" in his wife's name for his children when he was able to show that the funds came from the sale of property belonging solely to him.

59 See Downey v. Duquesne City Bank, 146 Pa. Super. 289, 22 A.2d 124 (1941).

60 Pa. Stat. AnN. tit. 7, §819-904 (1939).

61 Pa. Stat. ANN. tit. 7, \$819-902 (1939).

62 See Pa. Stat. AnN. tit. 15, \$1074-608 (Supp. 1961) ; Pa. Stat. AnN. tit. 15, $\$ 1081.1$ (1958).

63 PA Stat. Ann. tit. 7, $\$ 819$ (1939), as amended, Pa. Stat. Ann. tit. 7, $\S \S 819-2$ to -1506 (1961). 
has received no notice of a different arrangement than the customary savings account trust-is maintained in a bank, the bank "may," upon proof of the death of the depositor, pay the funds to the person named as beneficiary of the account. This provision, together with section 902 , permits the bank to pay to a minor beneficiary, regardless of age, upon proof of the death of the depositor-trustee. ${ }^{64}$ Even though it would be fully protected if it paid the minor directly, the permissive language used in section 904 permits the bank to refuse to pay the minor and insist on the appointment of a guardian to receive the funds. ${ }^{65}$

Section 610 of the Building and Loan Code ${ }^{66}$ and section 3 of the Act of June 24, 1939 govern payments to minor beneficiaries of "in trust" accounts maintained in building and loan and federal savings and loan associations. Both provisions state that the association "shall" pay "dividends or earnings" and "withdrawal or maturity value" to a minor beneficiary if the "in trust" designation is the only notice of the trust given to the association; hence the associations are both required to pay and protected completely from claims of third parties.

The use in the Banking Code of permissive language and the corresponding use of mandatory language in the statutes governing associations indicates a legislative intention to restrict associations more than banks. Although insistence on a guardian might be of some benefit to the minor involved, an association would assume a risk of liability for damages which might be incurred by a minor while he was unable to reach his funds.

Pennsylvania's Uniform Gifts to Minors Act ${ }^{67}$ provides a new means by which a gift may be made to a minor. It does not, however, replace the "in trust" savings account method of making a gift. Gifts under the act are not testamentary in character, are carefully hedged with conditions, and are not subject to revocation. The donative concept in the Uniform Act is, in general, contrary and inapposite to the purposes of a depositor who creates a tentative trust. The typical depositor of an "in trust" account is making a testamentary disposition, retaining to himself during his lifetime all the attributes of ownership of the account. He does not intend to create an irrevocable interest in the beneficiary when he opens the account. On the other hand, a gift pursuant to the Uniform Act can eliminate some of the uncertainties of "in trust" savings deposits-for example, creditors and spouse reach-

64 See Miller v. Beneficial Sav. Fund Soc'y, 36 Pa. D. \& C. 307 (C.P. 1939).

65 Ibid.

66 Pa. Stat. ANn. tit. 15, § 1074-610 (Supp. 1961).

67 PA. Stat. AnN. tit. 20, $\$ \S 3601-11$ (Supp. 1961). 
ing the funds, inadvertent revocation, and possible withdrawals by the beneficiary before a specified date. However, the statute is not a substitute for a tentative trust. It merely gives a prospective donor an additional vehicle by which he can make a gift; the vehicle selected depends on the intentions and purposes of the donor and the method best-suited to accomplish, them.

\section{B. Incompetent Depositors}

When a depositor becomes incompetent, several problems arise as to the disposition of the funds: (1) the right of the guardian to revoke the tentative trust and bring the account into the incompetent's general estate, (2) the responsibility of the fund for the living expenses of the incompetent and his family, and (3) the guardian's responsibility to safeguard the account.

The rules of the cases concerning the first two problems are summarized, albeit somewhat narrowly, in the Restatement of Trusts, under which rule the funds may be used only with the permission of the proper court and for the welfare of the depositor. Other authorities extend this to include the needs of the depositor's family and his burial expenses. ${ }^{60}$ The guardian's duty to safeguard the "in trust" account appears to require nothing more than holding the passbook in a safe place and thereby maintaining the status quo. ${ }^{70}$

\section{Tentative Trusts for Charitable Purposes}

The rules relating to savings accounts "in trust" for individuals generally apply to like accounts for charities. ${ }^{71}$ Moreover, tentative trusts for charities are subject to any restrictions relating generally to charitable gifts, inter vivos or testamentary. For example, in Pennsylvania any tentative trust established within thirty days of the depositor's death and naming a charity as beneficiary is probably void since such a transaction is clearly a "gift . . . made to take effect in possession or enjoyment at or after the death of the donor . . . " 72 And it seems that if revocable trusts-which actually involve some present transfer of property subject to recapture-violate restrictions on charitable gifts by will, tentative trusts are equally repugnant. ${ }^{73}$

68 See Restatearent (Second), Trusts $\$ 58$, comment c (1959).

60 See In re Derr, 83 Pa. D. \& C. 603 (C.P. 1952); In re Mines, 31 Pa. D. \& C. 153 (C.P. 1937) (dictum); Young v. Dollar Sav. Bank, 25 Pa. D. \& C. 80 (C.P. 1935) (dictum); 1 ScoTT, TRUSTs \$58.4, at 494 (2d ed. 1956). But see In re Newkirk, $27 \mathrm{~Pa}$ D. \& C. 675 (C.P. 1936).

70 Cf. Young v. Dollar Sav. Bank, supra note 69 ; In re Newkirk, supra note 69.

71 See 4 Scotr, Trusts $\$ \$ 361-62$ (2d ed. 1956).

72 PA. Stat. ANN. tit. 10, \& 17 (Supp. 1961).

73 See 4 ScotT, Trusts \$362.6, at 2612-13 (2d ed. 1956). 